\title{
Sphingolipid Delta(4)-Desaturase DES1
}

National Cancer Institute

\section{Source}

National Cancer Institute. Sphingolipid Delta(4)-Desaturase DES1. NCI Thesaurus. Code C104177.

Sphing olipid delta(4)-desaturase DES1 (323 aa, $\sim 38 \mathrm{kDa}$ ) is encoded by the human DEGS1 gene. This protein plays a role in fatty acid biosynthesis. 